\title{
Analisis Current Ratio, Debt To Equity Ratio, Dan Total Asset Turnover Terhadap Perubahan Laba Pada Perusahaan Industri Barang Konsumsi Sektor Makanan Dan Minuman Yang Terdaftar Di Bursa Efek Indonesia Tahun 2014-2018
}

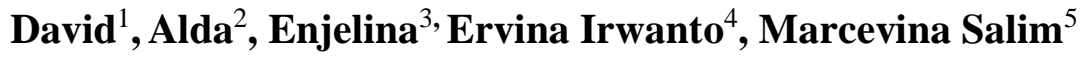 \\ 1,2,3,4,5 Fakultas Ekonomi Universitas Prima Indonesia \\ Email : aldaang13@gmail.com
}

\begin{abstract}
The company's main goal is to maximize profits. The company's profit is expected to increase every period, but the profits derived by the company in the future cannot be ascertained, so it is necessary to predict the changes in profits that occur from one period to the future. Changes in profits that occur in a company can be used as a basis for investors to determine whether they will make a purchase, sale or hold investment. The research aims to examine the effect of the current ratio, debt to equity ratio, and total asset turnover on earnings changes. This research uses a deductive, quantitative and descriptive approach. The population of food and beverage companies is 23 companies. By using purposive sampling, there are 13 companies that meet the criteria. The data analysis method used is multiple linear regression analysis, classic assumption test and hypothesis test. The results of this study indicate that both partially and simultaneously the current ratio, debt to equity ratio, and total asset turnover have no effect on earnings changes. The results of the coefficient of determination test show a negative number, which means that the variable changes in earnings cannot be explained by the independent variables used.
\end{abstract}

Keywords: Current Ratio; Debt to Equity Ratio; Total Asset Turnover and Change in Profit.

\begin{abstract}
ABSTRAK
Tujuan utama perusahaan adalah memaksimalkan laba. Laba perusahaan diharapkan setiap periode mengalami kenaikan namun laba yang diperoleh perusahaan di masa yang akan datang tidak dapat dipastikan, sehingga perlu dilakukan prediksi akan perubahan laba yang terjadi dari satu masa ke masa yang akan datang. Perubahan laba yang terjadi di suatu perusahaan dapat dijadikan dasar bagi para investor untuk menentukan apakah mereka akan melakukan pembelian, penjualan atau menahan investasi. Adapun penelitian ini bertujuan untuk menguji pengaruh current ratio, debt to equity ratio, dan total asset turnover terhadap perubahan laba. Penelitian ini menggunakan pendekatan deduktif, kuantitatif dan deskriptif. Populasi perusahaan makanan dan minuman ada 23 perusahaan. Dengan menggunakan sampling purposive maka sampel yang memenuhi kriteria ada sebanyak 13 perusahaan. Metode analisis data yang digunakan adalah analisis regresi linear berganda, uji asumsi klasik dan uji hipotesis. Hasil penelitian ini menunjukkan baik secara parsial maupun simultan current ratio, debt to equity ratio, dan total asset turnover tidak berpengaruh terhadap perubahan laba. Hasil uji koefisien determinasi menunjukkan angka negatif yang berarti variasi-variabel perubahan laba tidak dapat dijelaskan oleh variabel bebas yang digunakan.
\end{abstract}

Kata Kunci : Current Ratio; Debt to Equity Ratio; Total Asset Turnover dan Perubahan Laba. 


\section{PENDAHULUAN}

\subsection{Latar Belakang Masalah}

Tujuan utama perusahaan adalah memaksimalkan laba. Laba perusahaan diharapkan setiap periode mengalami kenaikan namun laba yang diperoleh perusahaan di masa yang akan datang tidak dapat dipastikan, sehingga perlu dilakukan prediksi akan perubahan laba yang terjadi dari satu masa ke masa yang akan datang. Perubahan laba yang terjadi di suatu perusahaan dapat dijadikan dasar bagi para investor untuk menentukan apakah mereka akan melakukan pembelian, penjualan atau menahan investasi mereka.

Investor pada umumnya mengukur keberhasilan perusahaan berdasarkan kemampuan perusahaan yang dapat dilihat dari kinerja keuangan. Salah satu parameter kinerja adalah laba. Laporan laba rugi merupakan laporan keuangan yang paling utama karena melaporkan hasil kegiatan dalam meraih keuntungan untuk periode tertentu.

Analisis laporan keuangan dapat dilakukan dengan perhitungan dan interprestasi melalui rasio keuangan. Rasio keuangan dapat memprediksi pertumbuhan laba di masa yang akan datang. Rasio keuangan dalam memprediksi perubahan laba pada penelitian ini adalah current ratio, debt to equity ratio dan total asset turnover. Current ratio yang tinggi menunjukkan aktiva lancar yang berlebih dalam menutupi kewajiban lancar perusahaan. Semakin tinggi current ratio maka perubahan laba yang diperoleh perusahaan semakin rendah dikarenakan current ratio yang tinggi menunjukkan adanya kelebihan aktiva lancar yang tidak baik terhadap profitabilitas perusahaan karena aktiva lancar menghasilkan return yang lebih rendah dibandingkan aktiva tetap.

Debt to equity ratio menunjukkan kemampuan modal sendiri perusahaan untuk memenuhi seluruh kewajibannya. Semakin tinggi debt to equity ratio maka perubahan laba yang diperoleh perusahaan semakin rendah dikarenakan debt to equity ratio yang tinggi menunjukkan adanya ketergantungan yang tinggi terhadap pihak luar dan risiko atas beban yang ditanggung oleh pemilik modal juga akan semakin besar. Total assets turnover merupakan rasio yang menunjukkan efektivitas penggunaan seluruh aktiva perusahaan dalam rangka menghasilkan penjualan. Semakin tinggi total assets turnover maka perubahan laba yang diperoleh perusahaan semakin tinggi. Hal ini dikarenakan total assets turnover yang tinggi menunjukkan perusahaan dapat memanfaatkan aktiva yang dimiliki untuk meningkatkan penjualan yang berdampak pada meningkatnya laba. Selain itu adanya ketidaksesuaian data dengan teori yang ada pada tiga perusahaan industri barang konsumsi sektor makanan dan minuman Periode 2014-2018 dapat dilihat melalui tabel 1.1. berikut ini.

Tabel 1. Fenomena Data Penelitian Tahun 2014-2018 (dalam Rupiah)

\begin{tabular}{rrrrrr}
\hline Kode & Tahun & \multicolumn{1}{c}{ Aktiva Lancar } & \multicolumn{1}{c}{ Hutang } & \multicolumn{1}{c}{ Penjualan } & \multicolumn{1}{c}{ Laba Bersih } \\
\hline \multirow{5}{*}{ DLTA } & 2014 & 854.176 .144 .000 & 227.473 .881 .000 & 879.253 .383 .000 & 288.073 .432 .000 \\
& 2015 & 902.006 .833 .000 & 188.700 .435 .000 & 699.506 .819 .000 & 192.045 .199 .000 \\
& 2016 & 1.048 .133 .697 .000 & 188.422 .642 .000 & 774.968 .268 .000 & 254.509 .268 .000 \\
& 2017 & 1.206 .576 .189 .000 & 196.197 .372 .000 & 777.308 .328 .000 & 279.772 .635 .000 \\
& 2018 & 1.384 .227 .944 .000 & 239.353 .356 .000 & 893.006 .350 .000 & 338.129 .985 .000 \\
& 2014 & 6.508 .768 .623 .440 & 6.190 .553 .036 .545 & 14.169 .088 .278 .238 & 409.824 .768 .594 \\
& 2015 & 7.454 .347 .029 .087 & 6.148 .255 .759 .034 & 14.818 .730 .635 .847 & 1.250 .233 .128 .560 \\
& 2016 & 8.739 .782 .750 .141 & 6.657 .165 .872 .077 & 18.349 .959 .898 .358 & 1.388 .676 .127 .665 \\
MYOR & 2017 & 10.674 .199 .571 .313 & 7.561 .503 .434 .179 & 20.816 .673 .946 .473 & 1.630 .953 .830 .893 \\
& 2018 & 12.647 .858 .727 .872 & 9.049 .161 .944 .940 & 24.060 .802 .395 .725 & 1.760 .434 .280 .304 \\
& 2014 & 379.496 .707 .512 & 331.624 .254 .750 & 1.480 .764 .903 .724 & 89.115 .994 .107 \\
& 2015 & 334.920 .076 .111 & 420.396 .809 .051 & 1.362 .245 .580 .664 & 40.150 .568 .620 \\
& 2016 & 519.269 .756 .899 & 633.267 .725 .358 & 1.501 .115 .928 .446 & 22.545 .456 .050 \\
SKBM & 2017 & 836.639 .597 .232 & 599.790 .014 .646 & 1.841 .487 .199 .828 & 25.880 .464 .791 \\
\hline & 2018 & 851.410 .216 .636 & 730.789 .419 .438 & 1.953 .910 .957 .160 & 15.954 .632 .472 \\
\hline
\end{tabular}

Sumber :www.idx.co.id

Pada PT. Delta Djakarta, Tbk aktiva lancar pada tahun 2016-2018 mengalami kenaikan begitu juga dengan laba bersihnya. Hutang pada tahun 2015 mengalami penurunan begitu juga dengan laba bersihnya mengalami penurunan. Hutang pada tahun 2017 dan 2018 mengalami kenaikan begitu juga 
dengan laba bersihnya.

Pada PT. Mayora Indah, Tbk aktiva lancar pada tahun 2015-2018 mengalami kenaikan begitu juga dengan laba bersihnya. Hutang pada tahun 2016- 2018 mengalami kenaikan begitu juga dengan laba bersihnya. Pada PT. Sekar Bumi, Tbk aktiva lancar tahun 2015 mengalami penurunan begitu juga dengan laba bersihnya mengalami penurunan. Aktiva lancar 2017 mengalami kenaikan begitu juga dengan laba bersihnya. Penjualan pada tahun 2016 dan 2018 mengalami kenaikan namun laba bersihnya mengalami penurunan. Berdasarkan uraian dan fenomena di atas, maka peneliti tertarik untuk melakukan penelitian dengan judul : "Analisis Current Ratio, Debt to Equity Ratio dan Total Asset Turn Over Terhadap Perubahan Laba Pada Perusahaan Industri Barang Konsumsi Sektor Makanan dan Minuman yang Terdaftar di Bursa Efek Indonesia Tahun 2014-2018”.

\section{Tinjauan Pustaka}

\subsection{Pengaruh Current Ratio Terhadap Perubahan Laba}

Menurut Pramono (2015:350) Pengaruh current ratio terhadap perubahan laba adalah semakin tinggi current ratio, maka laba bersih yang dihasilkan perusahaan semakin sedikit, karena rasio lancar yang tinggi menunjukkan adanya kelebihan aktiva lancar yang tidak baik terhadap profitabilitas perusahaan karena aktiva lancar menghasilkan return yang lebih rendah dibandingkan aktiva tetap.

\subsection{Pengaruh Debt to Equity Ratio Terhadap Perubahan Laba}

Menurut Pramono (2015:350) Debt to equity ratio merupakan rasio yang digunakan untuk mengukur proporsi total aset yang dibiayai oleh kreditor. Makin tinggi Debt to equity ratio, makin besar financial leverage dan makin besar pula dana kreditor yang digunakan untuk menghasilkan laba. DER berpengaruh negatif hal ini disebabkan karena sebagian investor menganggap bahwa DER dipandang sebagai besarnya tanggung jawab perusahaan terhadap pihak ketiga yaitu kreditor yang memberikan pinjaman kepada perusahaan. Sehingga semakin besarnilai DER akan memperbesar tanggungan perusahaan. DER yang terlalu tinggi mempunyai dampak buruk terhadap kinerja perusahaan, karena dengan tingkat utang yang semakin tinggi berarti beban bunga perusahaan akan semakin besar dana akan mengurangi keuntungan.

Menurut Hutabarat (2013:202) DER yang semakin besar menunjukkan kewajiban perusahaan semakin tinggi, terutama dalam membayar bunga, yang dapat berakibat makin rendah laba bersih perusahaan. Makin rendahnya laba bersih menyebabkan perubahan laba perusahaan akan menurun.

\subsection{Pengaruh Total Asset Turn Over Terhadap Perubahan Laba}

Menurut Pramono (2015:351) TATO merupakan perbandingan antar penjualan bersih terhadap total asset. TATO berfungsi untuk mengukur kemampuan perusahaan menggunakan total aktivanya dalam menghasilkan penjualan bersih. Semakin besar TATO menunjukkan semakin efisiensi penggunaan seluruh aktiva perusahaan untuk menunjang kegiatan penjualan. Hal ini menunjukan bahwa kinerja perusahaan semakin baik, dengan demikian para investor tertarik untuk menanamkan modalnya, sehingga dapat meningkatkan laba perusahaan.

Menurut Hutabarat (2013:202) Semakin tinggi TATO yang dihasilkan menunjukkan perusahaan menghasilkan cukup banyak volume bisnis sehingga perusahaan dapat meningkatkan nilai penjualan. Nilai penjualan yang makin tinggi berpotensi menghasilkan laba bersih yang semakin tinggi dan pada akhirnya dapat meningkatkan perubahan laba perusahaan.

\subsection{Penelitian Terdahulu}

Penelitian-penelitian terdahulu yang digunakan sebagai perbandingan dalam penelitian ini adalah: 
Tabel 2. Penelitian Terdahulu

\begin{tabular}{|c|c|c|c|c|}
\hline No & Nama & Judul Penelitian & $\begin{array}{c}\text { Variabel } \\
\text { Penelitian }\end{array}$ & Hasil Penelitian \\
\hline 1 & $\begin{array}{c}\text { Ifada dan } \\
\text { Puspitasar } \\
\text { i } \\
(2016)\end{array}$ & $\begin{array}{l}\text { Analisis Pengaruh } \\
\text { Rasio Keuangan } \\
\text { Terhadap } \\
\text { Perubahan Laba }\end{array}$ & $\begin{array}{l}\text { Variabel } \\
\text { Independen: } \\
\text { CR, DAR, DER, } \\
\text { TATO, GPM dan } \\
\text { NPM } \\
\text { Variabel } \\
\begin{array}{l}\text { Dependen : } \\
\text { perubahan laba }\end{array}\end{array}$ & $\begin{array}{l}\text { Secara simultan CR, DAR, DER, } \\
\text { TATO, GPM dan NPM berpengaruh } \\
\text { terhadap perubahan laba } \\
\text { Secara parsial CR dan DAR } \\
\text { berpengaruh negative terhadap } \\
\text { perubahan laba, TATO, GPM dan NPM } \\
\text { berpengaruh positif dan signifikan } \\
\text { terhadap perubahan laba, DER tidak } \\
\text { berpengaruh terhadap perubahan laba }\end{array}$ \\
\hline 2 & $\begin{array}{c}\text { Pramono } \\
\text { (2015) }\end{array}$ & $\begin{array}{l}\text { Pengaruh Current } \\
\text { Ratio, Working } \\
\text { Capital To Total } \\
\text { Assets, Debt to } \\
\text { Equity Ratio, Total } \\
\text { Assets Turnover } \\
\text { Dan Profit Margin } \\
\text { Terhadap } \\
\text { Perubahan Laba }\end{array}$ & $\begin{array}{l}\text { Variabel } \\
\text { Independen: } \\
\text { CR, WCTA, } \\
\text { DER, TATO dan } \\
\text { NPM } \\
\text { Variabel } \\
\text { Dependen : } \\
\text { perubahan laba }\end{array}$ & $\begin{array}{l}\text { Secara simultan CR, WCTA, DER, } \\
\text { TATO dan NPM berpengaruh terhadap } \\
\text { perubahan laba } \\
\text { Secara parsial CR dan DER berpengaruh } \\
\text { negatif terhadap perubahan laba, WCTA } \\
\text { tidak berpengaruh terhadap perubahan } \\
\text { laba, TATO berpengaruh positif } \\
\text { terhadap perubahan laba }\end{array}$ \\
\hline 3 & $\begin{array}{c}\text { Janrosl } \\
(2015)\end{array}$ & $\begin{array}{l}\text { Pengaruh Inventory } \\
\text { Turnover, Total } \\
\text { Asset Turnover Dan } \\
\text { Net Profit Margin } \\
\text { Terhadap } \\
\text { Perubahan Laba } \\
\text { Pada Perusahaan } \\
\text { Manufaktur Yang } \\
\text { Terdaftar Di Bursa } \\
\text { Efek Indonesia }\end{array}$ & $\begin{array}{l}\text { Variabel } \\
\text { Independen: } \\
\text { Inventory } \\
\text { Turnover, Total } \\
\text { Asset Turnover } \\
\text { Dan Net Profit } \\
\text { Margin } \\
\text { Variabel } \\
\begin{array}{l}\text { Dependen : } \\
\text { perubahan laba }\end{array}\end{array}$ & $\begin{array}{l}\text { Secara simultan Inventory Turnover, } \\
\text { Total Asset Turnover Dan Net Profit } \\
\text { Margin berpengaruh terhadap perubahan } \\
\text { laba } \\
\text { Secara parsial Inventory Turnover } \\
\text { berpengaruh negatif terhadap perubahan } \\
\text { laba sedangkan Total Asset Turnover } \\
\text { Dan Net Profit Margin tidak } \\
\text { berpengaruh terhadap perubahan laba }\end{array}$ \\
\hline
\end{tabular}

\subsection{Kerangka Konseptual}

Kerangka konseptual menunjukkan hubungan antara variabel-variabel yang akan diuji dan diteliti. Berdasarkan latar belakang dan tinjauan pustaka, maka peneliti dapat membuat kerangka konseptual sebagai berikut :

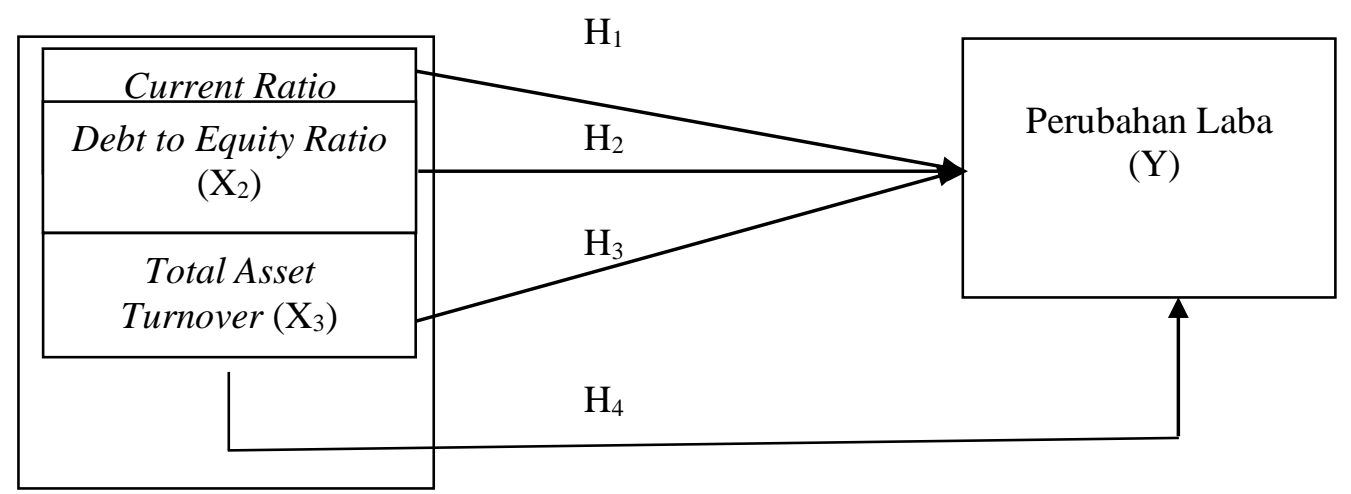

Gambar 1. Kerangka Konseptual 


\subsection{Hipotesis}

Hipotesis dalam penelitian ini adalah:

$\mathrm{H}_{1} \quad$ : Current Ratio berpengaruh secara parsial terhadap perubahan laba pada perusahaan industri barang konsumsi sektor makanan dan minuman yang terdaftar di Bursa Efek Indonesia tahun 2014-2018.

$\mathrm{H}_{2}$ : Debt to Equity Ratio berpengaruh secara parsial terhadap perubahan laba pada perusahaan industri barang konsumsi sektor makanan dan minuman yang terdaftar di Bursa Efek Indonesia tahun 2014-2018.

$\mathrm{H}_{3} \quad$ : Total Asset Turnover berpengaruh secara parsial terhadap perubahan laba pada perusahaan industri barang konsumsi sektor makanan dan minuman yang terdaftar di Bursa Efek Indonesia tahun 2014-2018.

$\mathrm{H}_{4} \quad$ : Current Ratio, Debt to Equity Ratio, dan Total Asset Turnover secara simultan berpengaruh terhadap perubahan laba pada perusahaan industri barang konsumsi sektor makanan dan minuman yang terdaftar di Bursa Efek Indonesia tahun 2014-2018.

\section{METODE PENELITIAN}

\subsection{Tempat dan Waktu Penelitian}

Penelitian ini dilakukan pada perusahaan industri barang konsumsi sektor makanan dan minuman yang terdaftar di Bursa Efek Indonesia melalui website www.idx.co.id. Waktu penelitian dari bulan Maret 2019 sampai dengan Juni 2020.

\subsection{Metode Penelitian}

\subsubsection{Pendekatan Penelitian}

Pendekatan penelitian yang digunakan adalah penelitian deduktif. Menurut Sujarweni (2014:12), penelitian deduktif adalah penelitian yang mempunyai sifat umum menjadi khusus artinya penelitian ini harus diawali dengan adanya sebuah teori yang sudah ada, kemudian diadakan penelitian untuk membuktikan teori yang sudah ada tersebut.

\subsubsection{Jenis Penelitian}

Jenis penelitian yang digunakan adalah penelitian kuantitatif. Menurut Sujarweni (2014:6), penelitian kuantitatif adalah jenis penelitian yang menghasilkan penemuan-penemuan yang dapat dicapai dengan menggunakan prosedur-prosedur statistik atau cara-cara lain dari kuantifikasi (pengukuran).

\subsubsection{Sifat Penelitian}

Sifat penelitian yang digunakan adalah penelitian deskriptif. Menurut Sujarweni (2014:11), penelitian deskriptif adalah penelitian yang dilakukan untuk mengetahui nilai masing-masing variabel, baik satu variabel atau lebih sifatnya independen tanpa membuat hubungan maupun perbandingan dengan variabel yang lain.

\subsection{Populasi dan Sampel}

Populasi yang digunakan dalam penelitian ini adalah semua perusahaan industri barang konsumsi sektor makanan dan minuman yang terdaftar (listed) di Bursa Efek Indonesia sejak tahun 2014 sampai dengan tahun 2018. Jumlah populasi dalam penelitian ini adalah berjumlah 23 perusahaan.

Teknik pengambilan sampel dalam penelitian ini adalah berdasarkan purposive sampling. Menurut Sugiyono (2017:85), sampling purposive adalah teknik penentuan sampel dengan pertimbangan tertentu. Adapun pertimbangan dalam pemilihan sampel pada penelitian adalah sebagai berikut:

1. Perusahaan industri barang konsumsi sektor makanan dan minuman yang terdaftar di Bursa Efek Indonesia.

2. Perusahaan industri barang konsumsi sektor makanan dan minuman yang mempublikasikan laporan keuangan secara lengkap berturut-turut selama tahun 2014-2018. 
3. Perusahaan industri barang konsumsi sektor makanan dan minuman yang memperoleh laba bersih positif selama tahun 2014-2018.

Tabel 3. Tabel Pemilihan Sampel

\begin{tabular}{clc}
\hline No & \multicolumn{1}{c}{ Keterangan } & Jumlah \\
\hline 1. & $\begin{array}{l}\text { Perusahaan industri barang konsumsi sektor makanan dan minuman yang } \\
\text { terdaftar di BEI }\end{array}$ & 23 \\
& $\begin{array}{l}\text { Perusahaan industri barang konsumsi sektor makanan dan minuman yang tidak } \\
\text { mempublikasikan laporan keuangan secara lengkap berturut-turut selama tahun }\end{array}$ & \\
& 2014-2018 & \\
3. & Perusahaan industri barang konsumsi sektor makanan dan minuman yang tidak \\
& $\begin{array}{l}\text { memperoleh laba bersih positif selama tahun 2014-2018 } \\
\text { Jumlah sampel } \\
\text { Jumlah periode }\end{array}$ & $\mathbf{1 3}$ \\
Jumlah Observasi $=\mathbf{1 3} \mathbf{5}$ & $\mathbf{5}$ \\
\hline
\end{tabular}

Total jumlah observasi yang digunakan dalam penelitian ini yaitu 65 yang diambil dari jumlah sampel 13 perusahaan dikalikan dengan 5 tahun periode penelitian.

\subsection{Teknik Pengumpulan Data}

Metode pengumpulan data dalam penelitian ini dilakukan dengan studi dokumentasi yang merupakan teknik pengumpulan dengan cara mencatat, mengumpulkan, dan mempelajari data-data perusahaan terkait masalah yang sedang diteliti dengan bersumber dari laporan keuangan dan dokumen-dokumen yang berkaitan dengan perusahaan industri barang konsumsi sektor makanan dan minuman yang dipublikasikan oleh website resmi Bursa Efek Indonesia (BEI) sejak tahun 2014 sampai dengan 2018.

\subsection{Jenis dan Sumber Data Penelitian}

Jenis data yang digunakan dalam penelitian ini adalah data sekunder. Data sekunder tersebut diperoleh dari situs www.idx.co.id dalam bentuk laporan keuangan perusahaan industri barang konsumsi sektor makanan dan minuman tahun 2014-2018.

\subsection{Identifikasi dan Definisi Operasional Variabel Penelitian}

Adapun variabel yang digunakan dalam penelitian ini terdiri dari 3 variabel independen yaitu Current Ratio $\left(\mathrm{X}_{1}\right)$, Debt to Equity Ratio $\left(\mathrm{X}_{2}\right)$ dan Total Asset Turnover $\left(\mathrm{X}_{3}\right)$ sedangkan variabel dependen yang digunakan adalah perubahan laba (Y). Untuk lebih jelasnya identifikasi dan definisi operasional masing-masing variabel dapat dilihat pada tabel di bawah ini :

Tabel 4. Definisi Operasional dan Pengukuran Variabel

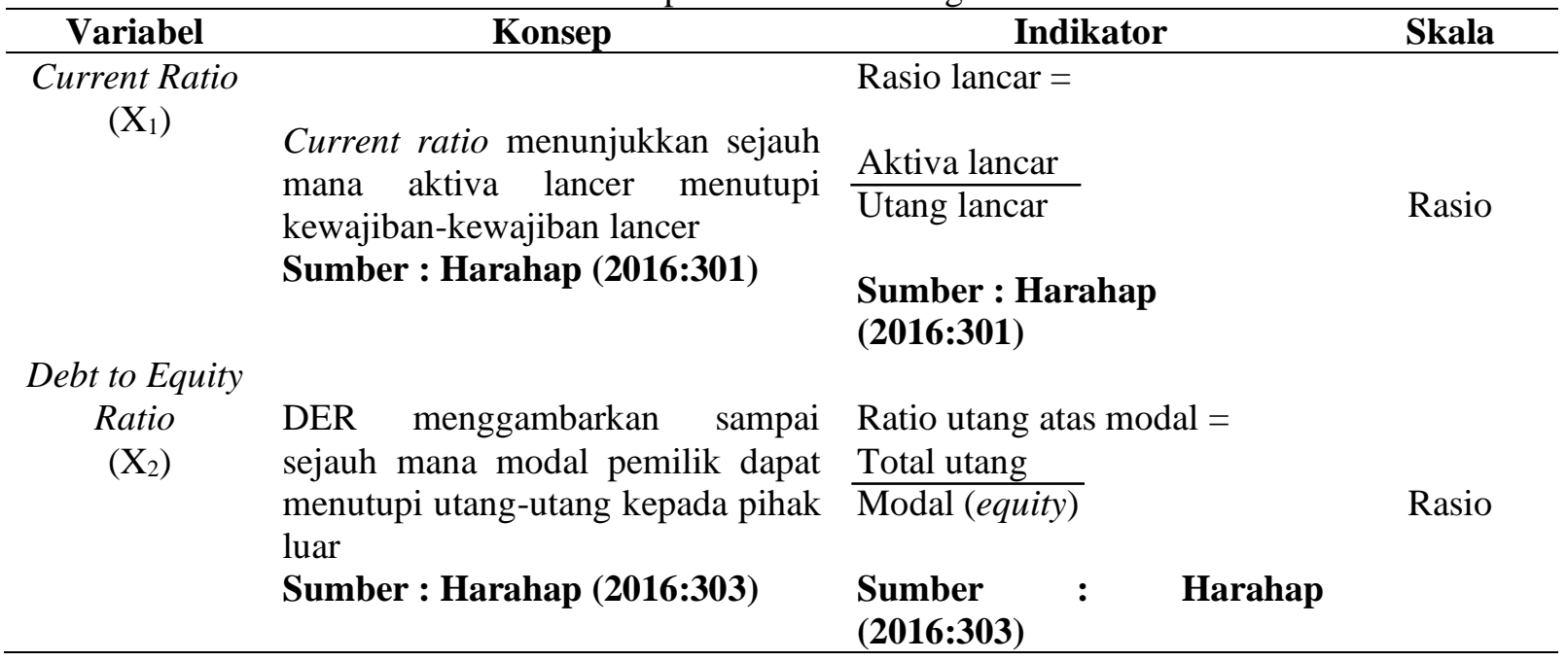




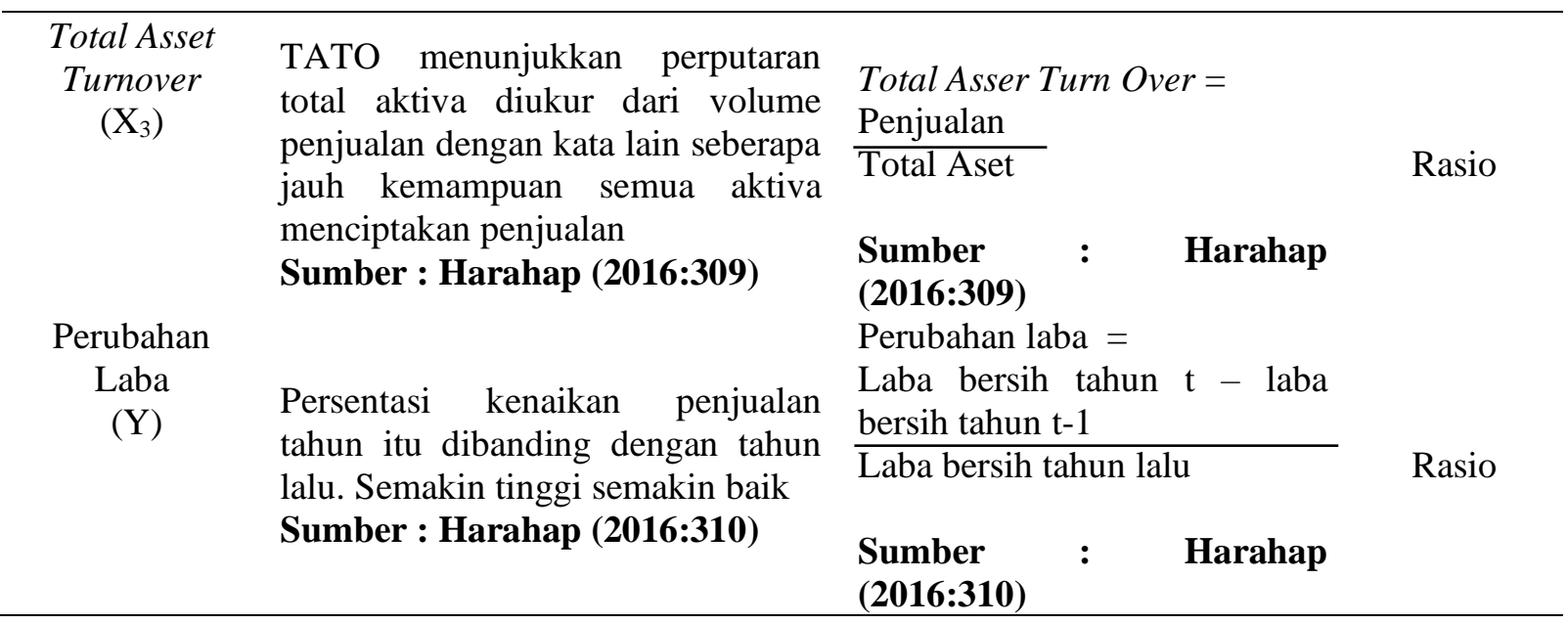

\subsection{Uji Asumsi Klasik}

Model regresi akan dapat dijadikan alat estimasi yang tidak bias jika telah memenuhi persyaratan BLUE (best linear unbiased estimator) yakni berdistribusi normal, tidak tidak terdapat multikolinearitas, terdapat heteroskedastistas dan tidak terdapat autokorelasi.

Pengujian asumsi klasik pada penelitian ini terdiri dari 4 alat uji yaitu uji normalitas, uji multikolinearitas, uji autokorelasi dan uji heteroskedastisitas.

\subsection{Model Analisis Data Penelitian}

\subsubsection{Model Penelitian}

Pengujian hipotesis pada penelitian ini untuk menguji apakah variabel independen berpengaruh secara parsial maupun simultan terhadap variabel dependen menggunakan uji $\mathrm{F}$ dan uji $\mathrm{t}$. Adapun model regresi yang digunakan adalah analisis regresi berganda dengan rumus :

Keterangan:

$$
\mathrm{Y}=\mathrm{a}+\mathrm{b}_{1} \mathrm{X}_{1}+\mathrm{b}_{2} \mathrm{X}_{2}+\mathrm{b}_{3} \mathrm{X}_{3}+\mathrm{e}
$$

\begin{tabular}{|c|c|}
\hline Y & $=$ Perubahan Laba \\
\hline $\mathrm{a}$ & $=$ Konstanta \\
\hline $\mathrm{X}_{1}$ & $=$ Current Ratio \\
\hline $\mathrm{X}_{2}$ & $=$ Debt to Equity Ratio \\
\hline & $=$ Total Asset Turn Over \\
\hline $\mathrm{b}_{1}, \mathrm{~b}_{2}, \mathrm{~b}_{3}$ & $=$ Koefisien regresi \\
\hline & $=$ Variabel pengganggu \\
\hline
\end{tabular}

\subsection{2}

\section{Koefisien Determinasi}

Koefisien determinasi pada regresi linear sering diartikan sebagai seberapa besar kemampuan semua variabel bebas dalam menjelaskan varians dari variabel terikatnya. Pada penelitian ini koefisien determinasi dilihat pada nilai Adjusted $R$ Square dikarenakan variabel bebas yang digunakan lebih dari 3 variabel.

\subsubsection{Uji t}

Uji t untuk menguji bagaimana pengaruh masing-masing variabel bebasnya secara parsial terhadap variabel terikatnya. Uji ini dapat dilakukan dengan mambandingkan $t$ hitung dengan $t$ tabel atau dengan melihat kolom signifikansi pada masing-masing t hitung, Adapun kriteria sebagai pedoman uji $t$ adalah sebagai berikut :

$\mathrm{H}_{0}$ diterima jika $-\mathrm{t}_{\text {tabel }} \leq \mathrm{t}_{\text {hitung }} \leq \mathrm{t}_{\text {tabel }}$ dan signifikan $>0,05$

$\mathrm{H}_{\mathrm{a}}$ diterima jika $-\mathrm{t}_{\text {hitung }}<-\mathrm{t}_{\text {tabel }}$ atau $\mathrm{t}_{\text {hitung }}>\mathrm{t}_{\text {tabel }}$ dan signifikan $<0,05$

\subsubsection{Uji F}

Uji $F$ adalah uji untuk melihat apakah semua variabel bebasnya secara bersama-sama 
berpengaruh terhadap variabel terikatnya. Uji $\mathrm{F}$ dapat dilakukan dengan membandingkan $\mathrm{F}$ hitung dengan F Tabel.

$\mathrm{H}_{0}$ diterima jika $\mathrm{F}_{\text {hitung }}<\mathrm{F}_{\text {tabel }}$ dan signifikan $>0,05$

$\mathrm{H}_{\mathrm{a}}$ diterima jika $\mathrm{F}_{\text {hitung }}>\mathrm{F}_{\text {tabel }}$ dan signifikan $<0,05$

\section{HASIL DAN PEMBASAHAN}

\subsection{Statistik Deskriptif}

Sampel yang memenuhi kriteria pada penelitian ini berjumlah 13 perusahaan dengan periode penelitian 5 tahun (2014-2018) sehingga data berjumlah 65 data. Berikut ini adalah gambaran data minimum, maksimum, rata-rata dan simpangan baku (standard deviasi) dari masing-masing variabel :

Tabel 5. Statistik Deskriptif

Descriptive Statistics

\begin{tabular}{|l|r|r|r|r|r|}
\hline & \multicolumn{1}{|c|}{ N } & Minimum & Maximum & \multicolumn{1}{c|}{ Mean } & Std. Deviation \\
\hline CR & 65 &, 514 & 8,638 & 2,27468 & 1,702935 \\
DER & 65 &, 164 & 3,029 &, 97389 &, 567197 \\
TATO & 65 &, 546 & 3,514 & 1,26571 &, 616410 \\
Perubahan_Laba & 65 &,- 596 & 2,051 &, 14628 &, 488825 \\
Valid N (listwise) & 65 & & & & \\
\hline
\end{tabular}

Nilai minimum pada variabel Current Ratio bernilai 0,514 yang diperoleh PT. Multi Bintang Indonesia, Tbk tahun 2014 sedangkan nilai maksimum Current Ratio sebesar 8,638 diperoleh PT. Delta Djakarta, Tbk pada tahun 2017. Nilai rata-rata Current Ratio perusahaan industri barang konsumsi sektor makanan dan minuman yang terdaftar di Bursa Efek Indonesia periode 2014-2018 sebesar 2,27468.

Nilai minimum pada variabel Debt to Equity Ratio bernilai 0,164 yang diperoleh PT. Ultrajaya Milk Industry \& Trading Company, Tbk tahun 2018 sedangkan nilai maksimum Debt to Equity Ratio sebesar 3,029 diperoleh PT. Multi Bintang Indonesia, Tbk tahun 2014. Nilai rata-rata Debt to Equity Ratio perusahaan industri barang konsumsi sektor makanan dan minuman yang terdaftar di Bursa Efek Indonesia periode 2014-2018 sebesar 0,97389.

Nilai minimum pada variabel Total Asset Turnover bernilai 0,546 yang diperoleh PT. Nippon Indosari Corporindo, Tbk tahun 2017 sedangkan nilai maksimum Total Asset Turnover sebesar 3,514 diperoleh PT. Cahaya kalbar, Tbk tahun 2014. Nilai rata-rata Total Asset Turnover perusahaan industri barang konsumsi sektor makanan dan minuman yang terdaftar di Bursa Efek Indonesia periode 20142018 sebesar $1,26571$.

Nilai minimum pada variabel Perubahan laba bernilai -0,596 yang diperoleh PT. Mayora Indah, Tbk tahun 2014 sedangkan nilai maksimum Perubahan laba sebesar 2,051 diperoleh PT. Mayora Indah, Tbk tahun 2015. Nilai rata-rata Perubahan laba perusahaan industri barang konsumsi sektor makanan dan minuman yang terdaftar di Bursa Efek Indonesia periode 2014-2018 sebesar 0,14628 . 


\subsection{Uji Asumsi Klasik}

\subsubsection{Uji Normalitas}

Adapun hasil uji normalitas pada penelitian ini adalah sebagai berikut:

Tabel 6. Uji Normalitas Kolmogorov Smirnov

One-Sample Kolmogorov-Smirnov Test

\begin{tabular}{|ll|r|}
\hline & & $\begin{array}{r}\text { Unstandardiz } \\
\text { ed Residual }\end{array}$ \\
\hline Normal Parameters & a,b & Mean \\
Most Extreme Differences & Std. Deviation &, 0000000 \\
& Absolute &, 48379878 \\
& Positive &, 124 \\
Kolmogorov-Smirnov Z & Negative &, 124 \\
Asymp. Sig. (2-tailed) & &,- 073 \\
\end{tabular}

a. Test distribution is Normal.

b. Calculated from data.

Dari tabel IV.3 dapat dilihat jika nilai signifikan sebesar 0,267 yang mana nilai ini telah lebih besar dari 0,05 maka dapat disimpulkan data pada penelitian ini telah berdistribusi normal.

\subsubsection{Uji Multikolinearitas}

Uji multikolinearitas merupakan uji syarat kedua setelah normalitas. Untuk melihat apakah diantara variabel independen tidak terdapat korelasi maka dapat dilihat nilai tolerance dan VIF.

Tabel 7. Uji Multikolinearitas

\begin{tabular}{|c|c|c|c|}
\hline \multicolumn{4}{|c|}{ Coefficients $^{a}$} \\
\hline \multirow{2}{*}{\multicolumn{2}{|c|}{ Model }} & \multicolumn{2}{|c|}{ Collinearity Statistics } \\
\hline & & Tolerance & VIF \\
\hline \multirow[t]{3}{*}{1} & CR &, 536 & 1,867 \\
\hline & DER &, 534 & 1,874 \\
\hline & TATO &, 961 & 1,040 \\
\hline
\end{tabular}

Dari hasil uji multikolinearitas menunjukkan data pada penelitian ini tidak terjadi multikolinearitas karena nilai tolerance semua variabel $>0,10$ dan nilai VIF semua variabel $<10$ yang berarti bahwa tidak terdapat korelasi di antara variabel independen yang digunakan.

\subsubsection{Uji Autokorelasi}

Pada penelitian time series wajib dilakukan uji autokorelasi. Berikut ini hasil uji autokorelasi menggunakan metode uji Durbin Watson: 
Tabel 8. Uji Autokorelasi

Model Summary

\begin{tabular}{|l|l|r|r|r|r|}
\hline Model & $\mathrm{R}$ & $\mathrm{R}$ Square & $\begin{array}{c}\text { Adjusted } \mathrm{R} \\
\text { Square }\end{array}$ & $\begin{array}{c}\text { Std. Error of } \\
\text { the Estimate }\end{array}$ & $\begin{array}{c}\text { Durbin- } \\
\text { Watson }\end{array}$ \\
\hline 1 &, $143^{\mathrm{a}}$ &, 020 &,- 028 &, 495553 & 1,788 \\
\hline
\end{tabular}

a. Predictors: (Constant), TATO, CR, DER

b. Dependent Variable: Perubahan_Laba

Dengan melihat pada pedoman tabel DW; $\mathrm{k}=3$ dan $\mathrm{n}=65$ maka besarnya nilai :

$\mathrm{Dl}=1,5035 \quad 4-\mathrm{dl}=2,4965$

$\mathrm{Du}=1,6960 \quad 4-\mathrm{du}=2,304$

Sehingga dapat disimpulkan data penelitian tidak terjadi autokorelasi karena besarnya nilai $\mathrm{du}<\mathrm{Dw}<$ $4-$ du atau $1,6960<1,788<2,304$

\subsubsection{Uji Heteroskedastisitas}

Uji heteroskedastisitas pada penelitian ini menggunakan metode grafik dan statistik, dimana metode statistik yang dipilih menggunakan uji Park.

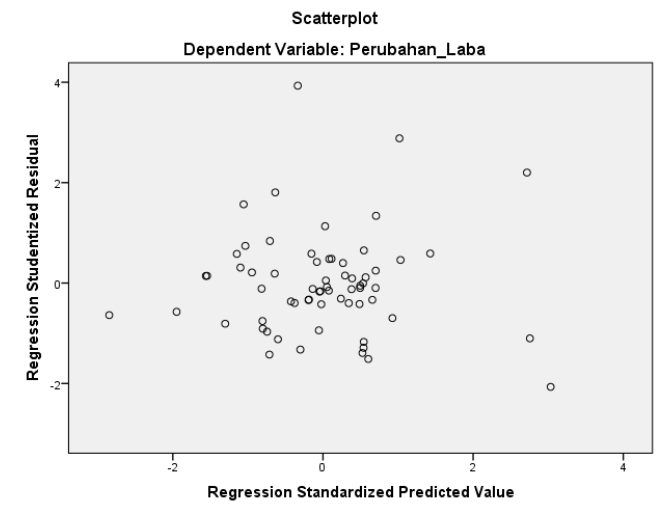

Gambar 2. Uji Heteroskedastisitas Scatterplot

Dari hasil uji grafik scatterplot data menunjukkan plot telah tersebar secara acak sehingga data pada penelitian ini telah memenuhi syarat uji asumsi klasik karena tidak terjadi heteroskedastisitas.

Tabel 9. Uji Park

Coefficients $^{\mathrm{a}}$

\begin{tabular}{|c|c|c|c|c|c|c|}
\hline \multirow[b]{2}{*}{ Mod } & & \multicolumn{2}{|c|}{ Unstandardized Coefficients } & \multirow{2}{*}{$\begin{array}{c}\text { Standardized } \\
\text { Coefficients }\end{array}$} & \multirow[b]{2}{*}{$\mathrm{t}$} & \multirow[b]{2}{*}{ Sig. } \\
\hline & & $\mathrm{B}$ & Std. Error & & & \\
\hline \multirow[t]{4}{*}{1} & (Constant) & $-5,350$ & 1,245 & & $-4,296$ &, 000 \\
\hline & CR & , 103 &, 226 & ,076 & ,456 & 650 \\
\hline & DER &, 765 & 679 & 188 & 1,126 & 264 \\
\hline & TATO & ,915 & ,466 & 245 & 1,965 &, 054 \\
\hline
\end{tabular}

a. Dependent Variable: InU2i

Dari hasil uji Park, menunjukkan data pada penelitian ini tidak terjadi heteroskedastisitas karena nilai signifikan tiga variabel independen (Current Ratio, Debt to Equity Ratio dan Total Asset Turnover) lebih besar dari batas nilai signifikan 0,05 . 


\subsection{Uji Hipotesis}

\subsubsection{Analisis Regresi Linear Berganda}

Tabel 10. Persamaan Analisis Regresi Linear Berganda

Coefficients $^{a}$

\begin{tabular}{|c|c|c|c|c|c|c|}
\hline \multirow{2}{*}{\multicolumn{2}{|c|}{ Model }} & \multicolumn{2}{|c|}{ Unstandardized Coefficients } & \multirow{2}{*}{$\begin{array}{c}\begin{array}{c}\text { Standardized } \\
\text { Coefficients }\end{array} \\
\text { Beta }\end{array}$} & \multirow[b]{2}{*}{$\mathrm{t}$} & \multirow[b]{2}{*}{ Sig. } \\
\hline & & $\mathrm{B}$ & Std. Error & & & \\
\hline \multirow[t]{4}{*}{1} & (Constant) & 201 &, 274 & &, 733 & 466 \\
\hline & $\mathrm{CR}$ &,- 022 &, 050 &,- 078 &,- 451 &, 653 \\
\hline & DER &,- 119 &, 150 &,- 138 &,- 798 & 428 \\
\hline & TATO & .089 & 103 & 112 & 868 & 389 \\
\hline
\end{tabular}

a. Dependent Variable: Perubahan_Laba

Dari hasil uji pada tabel IV.10 di atas dapat dibuat persamaan sebagai berikut :

Perubahan laba = 0,201 - 0,022 CR - 0,119 DER + 0,089 Total Asset Turnover

Dari persamaan regresi berganda tersebut dapat dijelaskan sebagai berikut :

1. Konstanta sebesar 0,201 menyatakan bahwa jika Current Ratio, Debt to Equity Ratio, dan Total Asset Turnover konstan atau bernilai 0 maka Perubahan laba sebesar 0,201 satuan.

2. Koefisien regresi Current Ratio sebesar -0,022 menyatakan bahwa setiap kenaikan Current Ratio 1 satuan akan menyebabkan penurunan Perubahan laba sebesar 0,022 satuan.

3. Koefisien regresi Debt to Equity Ratio sebesar -0,119 menyatakan bahwa setiap kenaikan Debt to Equity Ratio 1 satuan akan menyebabkan penurunan Perubahan laba sebesar 0,119 satuan.

4. Koefisien regresi Total Asset Turnover sebesar 0,089 menyatakan bahwa setiap kenaikan Total Asset Turnover 1 satuan akan menyebabkan peningkatan Perubahan laba sebesar 0,089 satuan.

\subsubsection{Koefisien Determinasi}

Tabel 11. Uji Koefisien Determinasi

Model Summary
\begin{tabular}{|l|c|c|c|c|}
\hline Model & $R$ & R Square & $\begin{array}{c}\text { Adjusted R } \\
\text { Square }\end{array}$ & $\begin{array}{c}\text { Std. Error of } \\
\text { the Estimate }\end{array}$ \\
\hline 1 &, $143^{\text {a }}$ &, 020 &,- 028 &, 495553 \\
\hline
\end{tabular}
a. Predictors: (Constant), TATO, CR, DER
b. Dependent Variable: Perubahan_Laba

Berdasarkan tabel IV.11 dapat dilihat Current Ratio, Debt to Equity Ratio dan Total Asset Turnover tidak dapat menjelaskan perubahan pada variabel perubahan laba pada perusahaan industri barang konsumsi sektor makanan dan minuman yang terdaftar di Bursa Efek Indonesia periode 20142018 karena nilai Adjusted R Square menunjukkan angka -0,028 yang sama dengan $0 \%$ yang berarti Current Ratio, Debt to Equity Ratio dan Total Asset Turnover tidak mempengaruhi perubahan laba pada perusahaan industri barang konsumsi sektor makanan dan minuman yang terdaftar di Bursa Efek Indonesia periode 2014-2018. 


\subsubsection{Uji F}

Tabel 12. Uji F

\begin{tabular}{|c|c|c|c|c|c|c|}
\hline \multicolumn{7}{|c|}{ ANOVA ${ }^{a}$} \\
\hline \multicolumn{2}{|c|}{ Model } & $\begin{array}{l}\text { Sum of } \\
\text { Squares }\end{array}$ & df & Mean Square & $\mathrm{F}$ & Sig. \\
\hline \multirow[t]{3}{*}{1} & Regression &, 313 & 3 & ,104 & .425 &, $736^{\mathrm{b}}$ \\
\hline & Residual & 14,980 & 61 &, 246 & & \\
\hline & Total & 15,293 & 64 & & & \\
\hline
\end{tabular}

a. Dependent Variable: Perubahan_Laba

b. Predictors: (Constant), TATO, CR, DER

Untuk mengetahui apakah variabel independen berpengaruh terhadap variabel dependen maka akan dibandingkan F hitung dengan F tabelnya. Dengan melihat pada tabel F untuk df 1 (3) dan df 2 (61) maka F tabel sebesar 2,76. Dengan demikian F hitung $(0,425)<\mathrm{F}$ tabel 2,76 dan nilai signifikan 0,736 > 0,05 maka Ho diterima yang artinya secara simultan Current Ratio, Debt to Equity Ratio dan Total Asset Turnover tidak berpengaruh signifikan terhadap Perubahan laba pada perusahaan industri barang konsumsi sektor makanan dan minumanyang terdaftar di Bursa Efek Indonesia periode 20142018.

\subsubsection{Uji t}

Tabel 13. Uji t

\begin{tabular}{|c|c|c|c|c|c|c|}
\hline \multicolumn{7}{|c|}{ Coefficients $^{a}$} \\
\hline \multirow{2}{*}{\multicolumn{2}{|c|}{ Model }} & \multicolumn{2}{|c|}{ Unstandardized Coefficients } & \multirow{2}{*}{$\begin{array}{c}\begin{array}{c}\text { Standardized } \\
\text { Coefficients }\end{array} \\
\text { Beta } \\
\end{array}$} & \multirow[b]{2}{*}{$t$} & \multirow[b]{2}{*}{ Sig. } \\
\hline & & B & Std. Error & & & \\
\hline \multirow[t]{4}{*}{1} & (Constant) & ,201 &, 274 & &, 733 & ,466 \\
\hline & $\mathrm{CR}$ &,- 022 &, 050 &,- 078 &,- 451 &, 653 \\
\hline & DER &,- 119 & 150 &,- 138 &,- 798 & 428 \\
\hline & TATO &, 089 & , 103 & 112 &, 868 & 389 \\
\hline
\end{tabular}

a. Dependent Variable: Perubahan_Laba

Besarnya t tabel pada probabilita 0,05 dengan tingkat uji signifikansi 2 arah dan df 61 adalah 1,99962. Maka hasil uji t pada penelitian ini dapat dijelaskan satu persatu sebagai berikut :

1. Current Ratio memiliki nilai $-\mathrm{t}_{\text {hitung }}>-\mathrm{t}_{\text {tabel }}$ atau $-0,451>-1,99962$ dan nilai signifikan 0,653 > 0,05 maka berarti Current Ratio tidak berpengaruh terhadap Perubahan laba pada perusahaan industri barang konsumsi sektor makanan dan minuman yang terdaftar di Bursa Efek Indonesia periode 2014-2018.

2. Debt to Equity Ratio memiliki nilai $-\mathrm{t}_{\text {hitung }}>-\mathrm{t}_{\text {tabel }}$ atau $-0,798>-1,99962$ dan nilai signifikan 0,561 > 0,05 maka berarti Debt to Equity Ratio tidak berpengaruh terhadap Perubahan labapada perusahaan industri barang konsumsi sektor makanan dan minuman yang terdaftar di Bursa Efek Indonesia periode 2014-2018.

3. Total Asset Turnover memiliki nilai $t_{\text {hitung }}<\mathrm{t}_{\text {tabel }}$ atau $0,868<1,99962$ dan nilai signifikan 0,389 > 0,05 maka berarti Total Asset Turnover tidak berpengaruh terhadap Perubahan labapada perusahaan industri barang konsumsi sektor makanan dan minuman yang terdaftar di Bursa Efek Indonesia periode 2014-2018.

\subsection{Pembahasan}

\subsubsection{Pengaruh Current Ratio terhadap Perubahan Laba}

Hasil penelitian membuktikan Current Ratio tidak berpengaruh terhadap Perubahan laba pada perusahaan industri barang konsumsi sektor makanan dan minuman yang terdaftar di Bursa Efek Indonesia periode 2014-2018. Hasil penelitan ini juga sejalan dengan Agustina dan Silvia (2012) yaitu 
CR tidak berpengaruh terhadap perubahan laba.

Tingkat likuiditas yang baik tidak selalu mencerminkan keadaan Current Ratio yang baik, hal ini dikarenakan pos pada aktiva lancar tidak produktif misalnya pada nilai piutang yang kebanyakan melebihi umur piutang yang seharusnya dikarenakan menurunnya daya konsumsi masyarakat dan nilai persediaan yang menumpuk di saat penjualan sedang lesu.

\subsubsection{Pengaruh Debt to Equity Ratio terhadap Perubahan Laba}

Hasil penelitian membuktikan Debt to Equity Ratio tidak berpengaruh terhadap Perubahan laba pada perusahaan industri barang konsumsi sektor makanan dan minuman yang terdaftar di Bursa Efek Indonesia periode 2014-2018. Hasil penelitan ini juga sejalan dengan hasil penelitian Ifada dan Puspitasari (2016) yaitu DER tidak mempunyai pengaruh terhadap perubahan laba.

Penggunaan hutang dapat memberikan dampak pada penurunan laba perusahaan, namun penggunaan hutang tidak selalu memberikan dampak negatif pada laba perusahaan sejauh perusahaan dapat memanfaatkan hutangnya dengan baik maka penggunaan hutang dapat meningkatkan laba yang menyebabkan adanya beban penggunaan hutang pada Debt to Equity Ratio tidak berpengaruh pada perubahan laba.

\subsubsection{Pengaruh Total Asset Turnover terhadap Perubahan Laba}

Hasil penelitian membuktikan Total Asset Turnover tidak berpengaruh terhadap Perubahan laba pada perusahaan industri barang konsumsi sektor makanan dan minuman yang terdaftar di Bursa Efek Indonesia periode 2014-2018. Hasil penelitan ini juga sejalan dengan Janrosl (2015) yaitu Total Asset Turnover tidak berpengaruh terhadap perubahan laba.

Untuk mendukung kegiatan penjualan yang baik maka perusahaan harus memiliki total aset yang besar, dimana aset ini dapat digunakan untuk mendukung kegiatan operasional perusahaan yang dapat digunakan sebagai modal kerja, namun jika perusahaan tidak memiliki aset yang cukup guna mendukung kegiatan operasionalnya dikarenakan sebagian besar aset tersebut didanai oleh hutang maka perusahaan akan kesulitan dalam menghasilkan keuntungan sehingga aset yang ada tidak dapat memberikan perubahan laba yang meningkat.

\section{SIMPULAN DAN REKOMENDASI}

\subsection{Kesimpulan}

Kesimpulan dari hasil penelitian ini yaitu :

1. Secara parsial Current Ratio tidak berpengaruh terhadap Perubahan laba pada perusahaan industri barang konsumsi sektor makanan dan minuman yang terdaftar di Bursa Efek Indonesia periode 2014-2018

2. Secara parsial Debt to Equity Ratio tidak berpengaruh terhadap Perubahan laba pada perusahaan industri barang konsumsi sektor makanan dan minuman yang terdaftar di Bursa Efek Indonesia periode 2014-2018

3. Secara parsial Total Asset Turnover tidak berpengaruh terhadap Perubahan laba pada perusahaan industri barang konsumsi sektor makanan dan minuman yang terdaftar di Bursa Efek Indonesia periode 2014-2018

4. Secara simultan Current Ratio, Debt to Equity Ratio dan Total Asset Turnover tidak berpengaruh terhadap Perubahan laba pada perusahaan industri barang konsumsi sektor makanan dan minuman yang terdaftar di Bursa Efek Indonesia periode 2014-2018

\subsection{Saran}

Saran yang dapat diberikan yang dapat bermanfaat adalah sebagai berikut :

1. Bagi peneliti selanjutnya disarankan untuk mengganti variabel lain yang mempengaruhi perubahan laba misalnya pertumbuhan penjualan, Debt to Asset Ratio, perputaran piutang, perputaran kas dan lain sebagainya. 
2. Bagi perusahaan industri barang konsumsi sektor makanan dan minuman disarankan agar memperhatikan pertumbuhan laba yang stabil dari waktu ke waktu karena pertumbuhan laba menunjukkan kinerja keuangan yang baik. Oleh karena itu perusahaan disarankan untuk mengoptimalkan produktivitas aktiva lancar, menjaga batas maksimal penggunaan hutang dan melakukan promosi untuk meningkatkan penjualan.

\section{DAFTAR PUSTAKA}

Agustina dan Silvia. 2012. Pengaruh rasio Keuangan terhadap Perubahan Laba pada Perusahaan Manufaktur yang Terdaftar di Bursa Efek Indonesia. Jurnal Wira Ekonomi Mikroskil. Vol. 2. No. 2.

Gumanti, Tatang Ary. 2011. Manajemen investasi Konsep, Teori dan Aplikasi. Jakarta: Mitra Wacana Media.

Harahap, Sofyan Safri. 2016. Analisis Kritis atas Laporan Keuangan. Jakarta : PT Raja Grafindo Persada.

Hutabarat, Susanna. 2013. Pengaruh rasio Likuiditas, Solvabilitas, Aktivitas, Profitabilitas dan Rasio Pasar terhadap Perubahan Laba. Jurnal MIX. Vol. III. No. 2.

Ifada, Luluk Muhimatul dan Tiara Puspitasari. 2016. Analisis Pengaruh Rasio Keuangan terhadap Perubahan Laba. Jurnal Akuntansi dan Auditing. Vol. 13. No. 1.

Janrosl, Viola Syukrina. 2015. Pengaruh Inventory Turnover, Total Asset Turnover dan Net Profit Margin terhadap Perubahan Laba pada Perusahaan Manufaktur yang Terdaftar di Bursa Efek Indonesia. Jurnal Magister Manajemen. Vol. 1 No. 2.

Pramono, Tanti Dwi. 2015. Pengaruh Current Ratio, Working Capital to Total Assets, Debt to Equity Ratio, Total Assets Turnover dan Profit Margin terhadap Perubahan Laba. Jurnal Akuntansi dan Sistem Teknologi Informasi. Vol. 11. Edisi Khusus.

Sugiyono. 2017. Metode Penelitian Kuantitatif Kualitatif dan R\&D. Bandung : PT. Alfabeta.

Suwarjeni, V. Wiratna. 2014. Metodologi Penelitian Lengkap, Praktis dan Mudah Dipahami. Yogyakarta : Pustaka Baru Press.

$\underline{\text { www.idx.co.id }}$ 